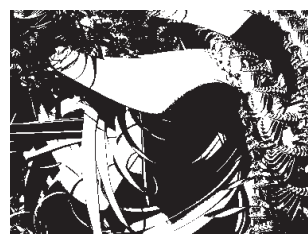

\title{
USKLAĐIVANJE POSLOVNOGA I OBITELJSKOGA ŽIVOTA U HRVATSKOJ: UTJECAJ NA FERTILITET
}

Anđelko AKRAP, Ivan ČIPIN

Ekonomski fakultet, Zagreb

UDK: $331.101 .232-055.2(497.5)$

$331.101 .25-055.2(497.5)$

$314.17(497.5): 331$

$314.145(497.5): 331$

Izvorni znanstveni rad

Primlieno: 16. 7. 2010.

Dvohraniteliski model obitelii postaje danas sve više norma u većini razvijenih zemalja. Cili ovoga rada jest ispitati koliko je razvijena infrastruktura za usklađivanje obiteljskoga i poslovnoga života i kakav model obitelji preferiraju zaposlene žene u Hrvatskoj. Iz anketnog istraživanja na uzorku od 1309 zaposlenih žena od 20 do 39 godina statističkim tehnikama ispitali smo preferirane oblike obitelii i stavove o položaju žena na tržištu rada. Rezultati pokazuju da među zaposlenim ženama velika većina preferira model dvaju hranitelja, gdje oba roditelja rade plaćeni posao izvan kućanstva. Isto tako, mlađe generacije žena imaju liberalnije stavove o položaju žena na tržištu rada. Povećati zaposlenost žena, a istodobno povećati fertilitet, sigurno nije i neće biti nimalo lak zadatak, no razina fertiliteta u pojedinim zemljama gdje je stopa zaposlenosti žena vrlo visoka pokazuje kako to nije nemoguće. Zaključujemo da je nemogućnost rada sa skraćenim radnim vremenom u Hrvatskoj zapreka za žene koje žele kombinirati profesionalne i obiteljske obveze.

Ključne riječi: fertilitet, usklađivanje poslovnih i obiteljskih obveza, zaposlene žene

Anđelko Akrap, Ekonomski fakultet Sveučilišta u Zagrebu, Trg J. F. Kennedyja 6, 10000 Zagreb, Hrvatska. 
Europska unija (EU), u skladu s Lisabonskim ciljevima ${ }^{1}$ da postane najkonkurentnije svjetsko gospodarstvo, suočava se sa dva važna demografska problema. Jedan je demografsko starenje i porast udjela starijega dijela populacije u ukupnoj, što stavlja sve veći pritisak na državne socijalne fondove, prije svega na državne sustave mirovinskog i zdravstvenog osiguranja. Drugi demografski problem, koji se neizravno tiče predmeta istraživanja ovoga rada, jest opadanje radno sposobnoga dijela stanovništva. Naime, kako bi povećao stopu zaposlenosti radnoga kontingenta, u uvjetima sve manjega priljeva mladih na tržište rada, EU je predložio povećanje stope zaposlenosti ženskoga stanovništva. Međutim, veći udio žena na tržištu rada mogao bi imati negativan učinak na ionako niske stope fertiliteta. Brewster i Rindfuss (2000.) tvrde kako žene na tržištu rada, odnosno njihovo ponašanje na njemu, leži u srži većine teorijskih objašnjenja kretanja stope fertiliteta i njezine promjene. Povezano s tim, ako želimo utjecati na povećanje vrlo niskih stopa fertiliteta, mjere koje bi ženama omogućile lakše usklađivanje posla i obitelji više su nego potrebne.

Dakle, negativni učinci niskih stopa fertiliteta izazvale su zabrinutost EU-a, koji u posljednje vrijeme stavlja sve veći naglasak na mjere koje će omogućiti ženama usklađivanje poslovnoga i obiteljskoga života, stoga je u kreiranju socijalne politike EU-a velik naglasak stavljen upravo na usklađivanje profesionalnoga i obiteljskoga života (European Commission, 2005.). Problematika usklađivanja posla i obitelji s demografskog je gledišta važna zbog utjecaja na fertilitet i fertilitetne intencije (Palomba, 2003.). Različito je institucionalno okruženje u europskim zemljama što se tiče mogućnosti usklađivanja poslovnih i obiteljskih obveza. Kod konceptualiziranja usklađivanja poslovnih i obiteljskih obveza pojedini autori razlikuju razne obiteljske modele (vidjeti npr. Esping-Andersen, 1999.). U analizi kako je posao usklađen s obiteljskim životom Kotowska i Matysiak (2008.) navode primjenu sljedećih modela koji se tiču obitelji i partnerstva:

1. model muškoga hranitelja obitelji (eng. male breadwinner): model u kojem je muškarac taj koji novčano pridonosi obitelji te radi s punim ili skraćenim radnim vremenom, dok žena ostaje kod kuće i brine se o kućanstvu i djeci. Ovaj model pretpostavlja potpuno odvajanje uloga muškarca i žene unutar obitelji, gdje se žena skrbi o kućanstvu i djeci (eng. homemaker-career), a muškarac je onaj koji ekonomski priskrbljuje (eng. economic provider)

2. modernizirani model muškoga hranitelja (eng. modernized male breadwinner): model prema kojem muškarac radi puno radno vrijeme, a žena radi sa skraćenim radnim vremenom. 
DRUŠ. ISTRAŽ. ZAGREB GOD. 20 (2011), BR. $1(111)$

STR. $47-68$

AKRAP, A., ČIPIN, I. USKLAĐIVANJE...

(1) TABLICA Zensko stanovništvo Hrvatske prema aktivnosti i dobi Popis 2001 .
Ovaj je model neka vrsta kompromisnog aranžmana, gdje žena ipak radi plaćeni posao izvan obitelji, ali kao tzv. sekundarni hranitelj, jer radi sa skraćenim radnim vremenom pa se automatski pretpostavlja da ima i nižu plaću od svoga partnera

3. dvohraniteljski model (eng. dual-earner model): model gdje oboje partnera rade ili puno radno vrijeme ili sa skraćenim radnim vremenom. Model dvaju hranitelja odnosi se na situaciju kada oba partnera podjednako ekonomski pridonose kućanstvu, odnosno imaju simetrične uloge na tržištu rada. S druge strane, što se tiče raspodjele obiteljskih obveza, model dvaju hranitelja razlikuje dva podtipa. Prvi je tzv. model dvaju hranitelja - dva skrbnika (eng. dual-earner-dual-career), koji pretpostavlja podjednaku podjelu poslova unutar obitelji, $\mathrm{u}$ prvom redu brigu o kućanskim poslovima i djeci. Taj je model u praksi još relativno rijedak i u većoj je mjeri, eventualno, prisutan $\mathrm{u}$ pojedinim nordijskim zemljama. Drugi je tzv. model dvostruke opterećenosti žene (eng. female double-burden model), prema kojem su žene odgovorne i za ekonomsko privređivanje i za brigu o obitelji, kućanstvu i djeci. Kod takva je modela ženama vrlo teško uskladiti obje sfere - obiteljsku i poslovnu. U praksi, vrlo je teško razlikovati ova dva modela, jer statistika tržišta rada ne pruža tu mogućnost, i zato su potrebna anketna istraživanja, poput ovoga u ovom radu.

Dakle, prema ova tri navedena modela, žene na tržištu rada u Hrvatskoj mogli bismo klasificirati u četiri osnovne grupe. U prvoj su one koje su neaktivne i izvan su tržišta rada. One pripadaju modelu muškoga hranitelja obitelji i, ako su u braku, u Hrvatskoj se popularno nazivaju "domaćice". Prema popisu stanovništva iz 2001., otprilike svaka šesta žena u tridesetim godinama života evidentirana je kao kućanica (vidjeti Tablicu 1).

\begin{tabular}{lrrrrrr}
\hline & & & Aktivne & & Neaktivne \\
& Ukupno aktivne & Zaposlene & Nezaposlene & & $\begin{array}{r}\text { Ukupno } \\
\text { neaktivne }\end{array}$ & $\begin{array}{r}\text { Od toga } \\
\text { kućanice }\end{array}$ \\
\hline $20-24$ & $60,99 \%$ & $37,45 \%$ & $23,53 \%$ & & $38,83 \%$ & $15,26 \%$ \\
$25-29$ & $79,88 \%$ & $58,61 \%$ & $21,28 \%$ & & $19,94 \%$ & $61,47 \%$ \\
$30-34$ & $81,20 \%$ & $63,27 \%$ & $17,93 \%$ & & $18,69 \%$ & $84,60 \%$ \\
$35-39$ & $81,05 \%$ & $66,09 \%$ & $14,96 \%$ & & $18,82 \%$ & $83,50 \%$
\end{tabular}

Iznos do $100 \%$ se odnosi na kategoriju nepoznato. Izvor: DZS (2001.)

U drugoj su grupi nezaposlene žene. One su prisutne na tržištu rada, ali relativno slabo ekonomski pridonose obitelji, posebice ako su nezaposlene duže vrijeme. Budući da nezaposlene žene nisu sasvim homogena skupina, njih je teže svr- 
DRUŠ. ISTRAŽ. ZAGREB GOD. 20 (2011) BR. 1 (1 111 1)

STR. $47-68$

AKRAP, A., ČIPIN, I. USKLAEIVANJE... stati $u$ jedan od tri navedena modela, jer jedan dio njih može prijeći iz statusa nezaposlenih $\mathrm{u}$ neaktivne, dok se druge mogu zaposliti. U trećoj su skupini žene koje su zaposlene, ali rade sa skraćenim radnim vremenom. No one su rijetko zastupljena kategorija, jer udio žena koje rade sa skraćenim radnim vremenom u Hrvatskoj je vrlo nizak (Eurostat, 2010.). I u četvrtoj, najbrojnijoj, grupi nalaze se zaposlene žene koje rade puno radno vrijeme.

Dvohraniteljski model obitelji postaje danas sve više norma u većini razvijenih zemalja (Roxburgh, 1999.). No zbog tih normativnih očekivanja, da žena kao i muškarac novčano pridonosi obitelji, dobar broj žena ima poteškoća prilikom usklađivanja poslovnih i obiteljskih obveza, ponajviše u skrbi za djecu. U društvima poput hrvatskoga, gdje su očekivanja o ulozi žene da se velikim dijelom brine o djeci visoka, a institucionalna potpora i infrastruktura zaposlenoj ženi majci nedostatna, njihov položaj sve je gori. Razlike među zemljama u brzini iščezavanja tradicionalnoga modela muškoga hranitelja obitelji i njegove zamjene dvohraniteljskim modelom od ključne su važnosti prilikom ocjene veze između stope fertiliteta i stope participacije žena na tržištu rada. U onim zemljama gdje je ta tranzicija uglavnom završila (poput nordijskih zemalja), stope fertiliteta relativno su visoke. Istodobno, $\mathrm{u}$ nekim drugim zemljama gdje još nije došlo do prave transformacije prema dvohraniteljskoj obitelji (zemlje južne Europe, pa i Hrvatska), stope fertiliteta relativno su niske, štoviše vrlo niske (vidjeti: Eurostat, 2010.).

Svrha je rada, na temelju anketnog istraživanja, prikazati preferirani model obitelji zaposlenih žena u Hrvatskoj. Istražit će se i stavovi zaposlenih žena o položaju žena na tržištu rada, ovisno o trenutačnom fertilitetu. U nastavku rada prvo se daje prikaz institucionalne potpore zaposlenim ženama majkama, prije svega rada sa skraćenim radnim vremenom na agregatnoj razini u zemljama EU-a i Hrvatskoj. Zatim se prvo teorijskom, a potom i empirijskom, analizom utvrđuje veza između zaposlenosti žena i fertiliteta. Na kraju se na temelju rezultata multivarijatne analize diskutira o preferiranim modelima zaposlenosti žena u Hrvatskoj.

\section{Institucionalna potpora zaposlenim majkama}

Ne negirajući ni ekonomske ni kulturološke činitelje niskoga fertiliteta, mnogi autori naglašavaju ulogu institucija u oblikovanju fertilitetnoga ponašanja pojedinaca i parova (Brewster i Rindfuss, 2000.; McDonald, 2000.; DiPrete i sur., 2003.). Ono što se često naglašava jest uloga države u pomoći ženama da usklade i kombiniraju posao i obitelj. ${ }^{2}$ Zato se nerijetko napominje da obiteljske politike imaju određenog učinka na ferti- 
DRUŠ. ISTRAŽ. ZAGREB GOD. 20 (2011), BR. 1 (111)

STR. $47-68$

AKRAP, A., ČIPIN, I. USKLAEIVANJE... litet (Neyer i Andersson, 2008.). U nesigurnim ekonomskim vremenima žene se na tržištu rada suočavaju s većim poteškoćama od muškaraca. Za određen broj žena koje postanu majke godinu do dvije nakon rođenja djeteta njihov profesionalni položaj doživi značajne promjene. Isto tako, žene imaju veći rizik od nezaposlenosti, teže im je zadržati posao i teže im se vratiti na tržište rada nakon izbivanja, npr. rodiljnoga dopusta. Stoga njihova obiteljska situacija ima ključnu ulogu u određivanju njihove ekonomske aktivnosti. Jedan od mogućih načina da se ženama omogući usklađivanje poslovnoga i obiteljskoga života te njihova lakšeg povratka na tržište rada nakon rodiljinog dopusta jest mogućnost rada sa skraćenim radnim vremenom (eng. part-time jobs). No "part-time" poslovi ipak nisu poslovi koje bismo mogli okarakterizirati kao karijerističke, i mnogim bi ženama, posebno onima visokoobrazovanima, takvi poslovi bili manje prihvatljivi. Rijetka iznimka jest Nizozemska, gdje uz zajedničku suradnju vlade, poslodavaca i sindikata postoje poslovi sa skraćenim radnim vremenom koji omogućuju stvaranje karijere kao normalan posao s punim radnim vremenom. Nizozemski tzv. Poldermodel primjer je uspješnoga konsenzusa uspostavljenog u 1990-ima, gdje poslodavci, sindikati i vlada zajednički rješavaju socioekonomske probleme, među njima i nizak fertilitet. Konsenzus se među ostalim odnosio i na ograničenje rasta plaća u zamjenu za više fleksibilnih poslova i poslova sa skraćenim radnim vremenom. Zajedno s ekspanzijom usluga za skrb o djeci, ti su sporazumi omogućili ženama lakše usklađivanje poslovnih i obiteljskih obveza (Liefbroer, 1999.). Jedno od mogućih rješenja za ublažavanje dvostrukoga tereta zaposlenoj ženi majci jest, dakle, dostupnost poslova i rad sa skraćenim radnim vremenom. Na grafikonu 1 prikazan je udio žena između 15 i 39 godina koje rade sa skraćenim radnim vremenom. Veza između udjela žena od 15 do 39 koje rade sa skraćenim radnim vremenom i totalne stope fertiliteta (TFR) u 2005. godini u Europi jaka je i pozitivna (koeficijent korelacije $r=0,623$, značajan na razini $p<0,01$ ). Osim u Nizozemskoj, najviše žena koje rade sa skraćenim radnim vremenom nalazimo u skandinavskim zemljama, a one su i poznate po visokoj fleksibilnosti tržišta rada, posebice za žene s malom djecom. Dakle, jedan od razloga vrlo visoke stope zaposlenosti ženskoga stanovništva u nordijskim zemljama jest upravo široka dostupnost poslova sa skraćenim radnim vremenom. Stoga je važno naglasiti da razlika između stope zaposlenosti žena među državama postoji zbog različite ponude i učestalosti poslova sa skraćenim radnim vremenom. U onim zemljama gdje je ponuda takvih poslova viša, u pravilu je viša i stopa zaposlenosti žena. 


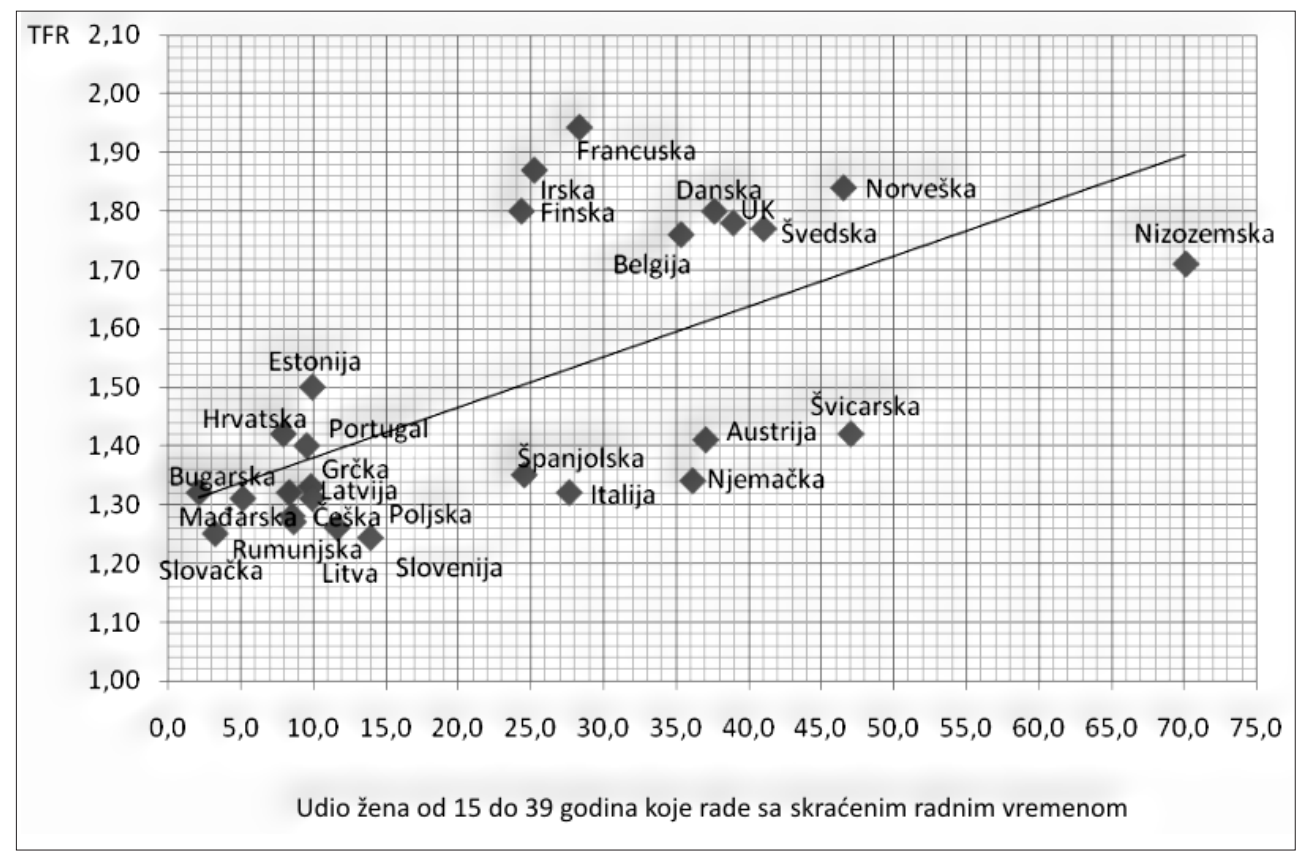

$\mathrm{r}=0,623, \mathrm{p}<0,01$. Izvor: Izračun autora na temelju podataka iz Eurostata (2010.)

$\rightarrow$ GRAFIKON 1

Veza između udjela žena od 15 do 39 godina koje rade sa skraćenim radnim vremenom i TFR-a 2005. godine
Ono što zaposlenim ženama u Hrvatskoj najviše priječi osiguravanje željenoga broja djece jest manjak fleksibilnosti na tržištu rada. U Hrvatskoj su poslovi sa skraćenim radnim vremenom rijetki, pa su udane žene prisiljene birati između posla s punim radnim vremenom ili ostati kod kuće kao kućanice. To nije nimalo poticajno okruženje za rađanje djece. Istraživanja pokazuju da je rad sa skraćenim radnim vremenom važan resurs prilikom usklađivanja poslovnih aktivnosti i obiteljskoga života (Del Boca, 2002.). Toga resursa u Hrvatskoj uvelike nedostaje, pa su žene u Hrvatskoj koje rade sa skraćenim radnim vremenom uglavnom majke, koje su se odlučile za tu opciju kako bi se mogle skrbiti za dijete.

\section{Zaposlenost žena i fertilitet}

Ne tako davno $u$ znanstvenoj se literaturi smatralo da je zaposlenost žena zapreka formiranju obitelji. Žene su počele raditi izvan kućanstva iz više razloga. Za udane je žene snažan motiv za zaposlenje bio viši životni standard, koji, uz samo jedan dohodak, nije bio lako ostvariv. Za neudane žene zaposlenost je pružala mogućnost slobode izbora ako nisu željele (još) ući u brak i ovisiti o suprugovu dohotku. Napokon, za sve žene zaposlenost je imala važnu ulogu u vlastitom samoostvarenju. Istodobno, rad žena izvan kućanstva nije bio kompatibilan s brigom o djeci i kućanskim poslovima. I prema 
DRUŠ. ISTRAŽ. ZAGREB GOD. 20 (2011), BR. 1 (111)

STR. $47-68$

AKRAP, A., ČIPIN, I. USKLA'ĐIVANJE... takvim shvaćanjima obrazovanje žena, plaćeni rad i zaposlenost izvan kućanstva rezultirao bi nižim fertilitetom. Empirijske studije iz 1960-ih i 1970-ih, kada je pad fertiliteta išao usporedno s rastom participacije žena na tržištu rada, dodatno su potvrdile takve stavove. Dokazi su bili toliko očiti da je negativna veza između zaposlenosti žena i fertiliteta bila jednostavno činjenica (vidjeti: Becker, 1991.). No novija demografska, ekonomska i sociološka literatura ne slaže se s idejom da zaposlenost žena mora uvijek negativno utjecati na fertilitet, a istraživanja upozoravaju na važnost politika za usklađivanje majčinstva sa zaposlenjem. Te politike u uvjetima participacije žena na tržištu rada mogu pozitivno djelovati na stopu fertiliteta (Bernhardt, 1993.; Brewster i Rindfuss, 2000.; McDonald, 2000.; Neyer, 2003.).

Potkraj 1980-ih došlo je do obrata veze između TFR-a i stope participacije žena na tržištu rada u razvijenim zemljama te je od negativne ta veza na agregatnoj razini postala pozitivna (Esping-Andersen, 1999.; Ahn i Mira, 2002.; Engelhardt i Prskawetz, 2004.; Billari i Kohler, 2004.). Jedno od najčešćih objašnjenja takva preokreta jest važnost društvenih normi i institucionalnog okruženja, koji pogoduju usklađivanju poslovnih i obiteljskih zadaća. Institucije i politike koje žele ženama pomoći oko usklađivanja tih dviju obveza - poput rodiljnoga dopusta, centara za skrb o djeci i dostupnost poslova sa skraćenim radnim vremenom - osjetno su manje dostupne u zemljama južne Europe, u Hrvatskoj i ostalim zemljama s vrlo niskim fertilitetom (Del Boca, 2002.; Delgado i sur., 2008.).

Veza između rasta participacije žena na tržištu rada i kretanja razine fertiliteta složena je i sigurno nije uniformna kada tu vezu promatramo na razini pojedinih zemalja. Razni regulatorni okviri na tržištima rada u zemljama s niskom stopom fertiliteta, zastupljenost rada sa skraćenim radnim vremenom, kulturne norme i tradicija oko zaposlenosti žena neki su od činitelja koji utječu na iskustva žena i parova u pogledu usklađivanja dviju već spomenutih sfera života. Usporedno s rastom udjela participacije žena na tržištu rada i radnoj snazi kretalo se i opadanje stope fertiliteta. Unutar dvohraniteljske obitelji, parovi suočeni s ograničenjima usklađivanja profesionalnih obveza i obiteljskoga života mogu izabrati strategiju da imaju manje djece. Djelomični razlog manjega broja djece, po mišljenju nekih autora (Clarkberg i Moen, 2001.), jest priroda posla koji obavljaju i koja im ne ostavlja mnogo vremena na obiteljskoj strani životnih prioriteta. Za razliku od individualne razine, veza između posla i obitelji na agregatnoj razini danas u Europi nije sasvim jasna. Ako po- 
DRUŠ. ISTRAŽ. ZAGREB GOD. 20 (2011), BR. 1 (111)

STR. $47-68$

AKRAP, A., ČIPIN, I. USKLADIVANJE...

gledamo stope zaposlenosti žena i stope fertiliteta $\mathrm{u}$ zemljama EU-a, ta povezanost ima pozitivan smjer. Na grafikonu 2 vidimo da je veza stope zaposlenosti žena u Europi od 25 do 49 godina i TFR-a srednje jaka i pozitivna. ${ }^{3}$ Naime, najniže stope fertiliteta nalazimo u zemljama gdje je i stopa zaposlenosti žena niska. To su većinom zemlje južne Europe (Italija, Španjolska, Grčka) i neke bivše socijalističke zemlje (Poljska, Slovačka, Mađarska). Naglasimo da se u ovoj grupi zemalja nalazi i Hrvatska.

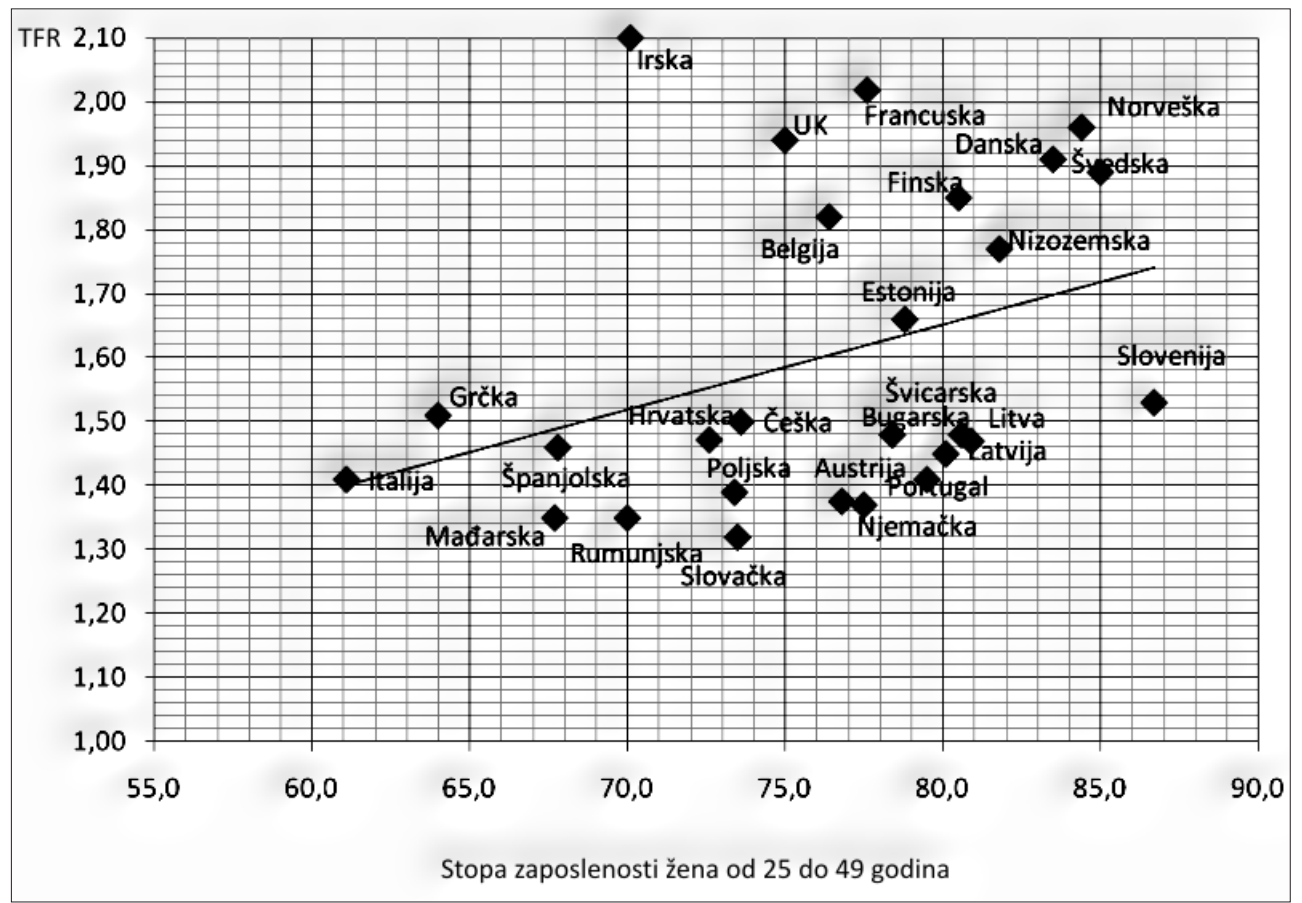

$\mathrm{r}=0,349, \mathrm{p}<0,01$. Izvor: Izračun autora na temelju podataka iz Eurostata (2010.)

i GRAFIKON 2

Veza između stope zaposlenosti žena od 25 do 49 godina i TFR-a 2008. godine
Infrastruktura za pomoć zaposlenoj ženi majci u Hrvatskoj ne zadovoljava. Žene i mladi u Hrvatskoj suočavaju se s nefleksibilnim tržištem rada, a samo tržište rada favorizira muškarce. Promjene se događaju, ali dosta sporo, unatoč tomu što žene sve više ulažu u ljudski kapital visokim obrazovanjem (Eurostat, 2010.). Bez obzira na stupanj obrazovanja, stope zaposlenosti žena u Hrvatskoj niže su od istih za muškarce za sve dobne skupine. Stanje na tržištu rada u Hrvatskoj u prvoj polovici 2000-ih bilo je lošije nego u većini zemalja EU-a. Stopa zaposlenosti i muškaraca i žena bila je relativno niska u usporedbi s prosjekom EU-27. Stopa nezaposlenosti u 2004. godini bila je među najvišima u Europi i iznosila je 11\%, što je za 3,5 postotna boda više od prosjeka EU-27 (Eurostat, 2010.). Posebno je visoka stopa nezaposlenosti mladih od 15 
DRUŠ. ISTRAŽ. ZAGREB GOD. 20 (2011), BR. 1 (111)

STR. $47-68$

AKRAP, A., ČIPIN, I. USKLAĐIVANJE...

(1) TABLICA 2

Stope zaposlenosti žena i muškaraca od 25 do 49 godina s djecom i bez djece mlađe od 15 godina 2006.

\begin{tabular}{|c|c|c|c|c|c|c|}
\hline \multirow[b]{2}{*}{ Zemlja } & \multirow[b]{2}{*}{ Žene } & \multirow{2}{*}{$\frac{\text { Bez djece }}{\text { Muškarci }}$} & \multirow{2}{*}{\multicolumn{2}{|c|}{$\frac{\text { S djecom }}{\text { Muškarci }}$}} & \multicolumn{2}{|r|}{ Razlika } \\
\hline & & & & & Žene & Muškarci \\
\hline Belgija & 75,8 & 81,4 & 72,4 & 91,4 & $-3,4$ & 10,0 \\
\hline Bugarska & 77,3 & 77,1 & 71,4 & 81,2 & $-5,9$ & 4,1 \\
\hline Češka & 84,8 & 87,8 & 68,3 & 93,7 & $-16,5$ & 5,9 \\
\hline Njemačka & 82,3 & 81,6 & 68,5 & 90,6 & $-13,8$ & 9,0 \\
\hline Estonija & 85,6 & 83,5 & 78,7 & 93,2 & $-6,9$ & 9,7 \\
\hline Grčka & 67,3 & 86,2 & 59,4 & 95,1 & $-7,9$ & 8,9 \\
\hline Španjolska & 75,0 & 84,1 & 60,6 & 91,3 & $-14,4$ & 7,2 \\
\hline Francuska & 79,9 & 81,1 & 72,0 & 91,3 & $-7,9$ & 10,2 \\
\hline Italija & 68,2 & 82,6 & 55,8 & 91,7 & $-12,4$ & 9,1 \\
\hline Latvija & 81,8 & 78,9 & 77,4 & 87,4 & $-4,4$ & 8,5 \\
\hline Litva & 83,0 & 78,0 & 80,1 & 88,1 & $-2,9$ & 10,1 \\
\hline Mađarska & 79,2 & 80,5 & 62,2 & 85,4 & $-17,0$ & 4,9 \\
\hline Nizozemska & 85,1 & 87,7 & 73,8 & 94,2 & $-11,3$ & 6,5 \\
\hline Austrija & 83,6 & 88,5 & 73,9 & 93,1 & $-9,7$ & 4,6 \\
\hline Poljska & 74,1 & 72,6 & 66,2 & 84,6 & $-7,9$ & 12,0 \\
\hline Portugal & 76,2 & 82,5 & 76,9 & 91,9 & 0,7 & 9,4 \\
\hline Rumunjska & 73,6 & 78,7 & 69,6 & 83,5 & $-4,0$ & 4,8 \\
\hline Slovenija & 79,0 & 83,1 & 85,6 & 93,2 & 6,6 & 10,1 \\
\hline Slovačka & 79,3 & 79,0 & 66,7 & 88,6 & $-12,6$ & 9,6 \\
\hline Finska & 81,8 & 80,4 & 76,8 & 92,5 & $-5,0$ & 12,1 \\
\hline UK & 85,6 & 85,5 & 68,4 & 90,9 & $-17,2$ & 5,4 \\
\hline
\end{tabular}

Izvor: Eurostat (2010.)

do 24 godine. Istraživanja u Hrvatskoj pokazuju da visoka stopa nezaposlenosti mladih utječe na odgađanje ulaska $u$ brak i rađanje djece (Akrap i Čipin, 2006.; Ilišin, 2007.).

Na početku 21. stoljeća u mnogim europskim zemljama stopa zaposlenosti žena na tržištu rada od 25 do 49 godina kreće se otprilike od $60 \%$ naviše. U skladu s tim broj tradicionalnih obitelji u kojima je muškarac (jedini) hranitelj obitelji zacijelo se smanjio. Stope zaposlenosti žena s djecom ${ }^{4}$ niže su ne samo od istih kod muškaraca nego i od onih kod žena koje nisu rodile (Tablica 2). Stopa zaposlenosti žena s djecom u svim zemljama, osim u Sloveniji i Portugalu, niža je od one kod žena koje nemaju djecu. Najveći utjecaj na stopu zaposlenosti žena s djecom nalazimo u UK, Mađarskoj, Češkoj, Španjolskoj, Njemačkoj, Slovačkoj, Italiji. Dakle, osim UK, riječ je o zemljama s vrlo niskim stopama fertiliteta. Istodobno, stope zaposlenosti muškaraca s djecom više su nego kod muškaraca koji nemaju djecu mlađu od 15 godina u svim analiziranim zemljama, što je u skladu s teorijskim pretpostavkama ekonomskih teorija fertiliteta (Becker, 1991.).

Kakva je situacija u Hrvatskoj? Činjenica je da je posao u Hrvatskoj prilično cijenjen. Prema Europskom istraživanju vrednota, više od $95 \%$ ispitanika drži posao vrlo važnim općenito i važnim u vlastitu životu (Baloban, 2005.). Vjerojatno 
DRUŠ. ISTRAŽ. ZAGREB GOD. 20 (2011) BR. $1(111)$

STR. $47-68$

AKRAP, A., ČIPIN, I. USKLADIVANJE...

(y) TABLICA 3

Zensko stanovništvo Hrvatske prema fertilitetnom statusu, aktivnosti i dobi, Popis 2001. je da mlađim generacijama žena i onima u fertilnom razdoblju zauzima važnije mjesto na ljestvici životnih prioriteta nego kod starijih generacija. Smatramo da plaćeni posao u vremenima ekonomske krize još više dobiva na važnosti.

Žensko stanovništvo u Hrvatskoj prema fertilitetnom statusu i aktivnosti pokazuje kako se fertilitetni status ekonomski aktivnih žena razlikuje od onoga kod neaktivnih žena. Osim u najmlađoj dobi (20-24, većinom studentice), žene koje nisu ekonomski aktivne natprosječno su rodile $\mathrm{u}$ odnosu na svoje vršnjakinje koje su zaposlene ili nezaposlene, tj. ekonomski aktivne. Prema podacima iz popisa stanovništva iz 2001. godine, u Hrvatskoj je u dobnoj skupini od 20 do 39 oko $3 / 4$ žena bilo ekonomski aktivno. ${ }^{5} \mathrm{U}$ to vrijeme stopa nezaposlenosti bila je vrlo visoka. Neki od načina prilagođavanja mladih žena u 1990-ima i 2000-ima u Hrvatskoj bili su povećana participacija $u$ višem i visokom obrazovanju, usavršavanje $\mathrm{u}$ struci te odlazak u inozemstvo (Pokos, 1999.). Premda su stope ekonomske aktivnosti žena u Hrvatskoj 2001. u promatranoj dobi nešto niže nego prema popisu stanovništva iz 1991. godine, bile bi i niže da žene nisu smanjile svoj fertilitet.

\begin{tabular}{lrrrrrr}
\hline & & $\begin{array}{r}\text { Ukupan } \\
\text { broj žena }\end{array}$ & Bez djece & $\begin{array}{r}\text { Broj žena } \\
\text { s djecom }\end{array}$ & $\begin{array}{r}\text { \% žena } \\
\text { bez djece }\end{array}$ & $\begin{array}{r}\% \text { žena } \\
\text { s djecom }\end{array}$ \\
\hline & $20-24$ & 149.892 & 119.669 & 30.223 & 79,84 & 20,16 \\
& $25-29$ & 145.831 & 68.174 & 77.657 & 46,75 & 53,25 \\
& $30-34$ & 147.511 & 33.949 & 113.562 & 23,01 & 76,99 \\
Ekonomski aktivne & $35-39$ & 158.767 & 22.685 & 136.082 & 14,29 & 85,71 \\
& $20-24$ & 91.414 & 69.488 & 21.926 & 76,01 & 23,99 \\
& $25-29$ & 116.496 & 56.955 & 59.541 & 48,89 & 51,11 \\
Zaposlene & $30-34$ & 119.779 & 30.225 & 89.554 & 25,23 & 74,77 \\
& $35-39$ & 128.682 & 19.381 & 109.301 & 15,06 & 84,94 \\
& $20-24$ & 56.140 & 42.733 & 13.407 & 76,12 & 23,88 \\
Nezaposlene & $25-29$ & 85.467 & 42.835 & 42.632 & 50,12 & 49,88 \\
& $30-34$ & 93.334 & 24.025 & 69.309 & 25,74 & 74,26 \\
& $35-39$ & 104.933 & 15.674 & 89.259 & 14,94 & 85,06 \\
& $20-24$ & 35.274 & 26.755 & 8.519 & 75,85 & 24,15 \\
& $25-29$ & 31.029 & 14.120 & 16.909 & 45,51 & 54,49 \\
& $30-34$ & 26.445 & 6200 & 20.245 & 23,44 & 76,56 \\
& $35-39$ & 23.749 & 3707 & 20.042 & 15,61 & 84,39 \\
& $20-24$ & 58.197 & 49.940 & 8257 & 85,81 & 14,19 \\
& $25-29$ & 29.077 & 11.029 & 18.048 & 37,93 & 62,07 \\
& $30-34$ & 27.575 & 3660 & 23.915 & 13,27 & 86,73 \\
& $35-39$ & 29.877 & 3226 & 26.651 & 10,80 & 89,20 \\
\hline
\end{tabular}

Izvor: DZS (2001.)

Obiteljske politike među zemljama mogu biti važan faktor u ovakvu kretanju fertiliteta i njegovu odnosu na kretanja na tržištu rada (Gauthier, 1996.). Olakšano usklađivanje obi- 
(1) TABLICA 4

Stope zaposlenosti žena i muškaraca od 25 do 49 godina prema broju djece, 2006. teljskoga i poslovnoga života prepoznato je kao tematika kojoj se treba dati veća važnost $u$ oblikovanju socijalne politike EU-a (Vignon, 2005.). Preferencije o trenutačnim i željenim uvjetima rada (rad na puno ili skraćeno radno vrijeme) ovise ponajprije o zahtjevima obiteljskoga života. Ta se zahtjevnost većinom iskazuje brojem djece i njihove dobi. Mogli bismo reći da je broj djece (trenutačan, ali i očekivani) jedan od glavnih indikatora obiteljskih obveza.

\begin{tabular}{|c|c|c|c|c|c|c|}
\hline & \multicolumn{3}{|c|}{$\begin{array}{l}\text { Muškarci } \\
\text { Broj djece }\end{array}$} & \multicolumn{3}{|c|}{$\begin{array}{r}\text { Žene } \\
\text { Broj djece }\end{array}$} \\
\hline & 1 & 2 & $3+$ & 1 & 2 & $3+$ \\
\hline Belgija & 91,2 & 93,7 & 87,1 & 75,9 & 76,3 & 58,0 \\
\hline Bugarska & 83,1 & 81,8 & 58,5 & 75,2 & 70,8 & 36,3 \\
\hline Češka & 92,9 & 95,6 & 88,4 & 69,4 & 70,9 & 51,3 \\
\hline Njemačka & 90,2 & 92,4 & 85,9 & 73,9 & 67,7 & 49,6 \\
\hline Estonija & 93,1 & 94,3 & 90,4 & 83,4 & 76,2 & 64,0 \\
\hline Grčka & 93,2 & 96,7 & 94,9 & 61,4 & 59,2 & 52,9 \\
\hline Španjolska & 90,2 & 92,6 & 90,9 & 64,7 & 58,1 & 50,3 \\
\hline Francuska & 90,5 & 92,5 & 90,2 & 77,5 & 73,9 & 56,7 \\
\hline Italija & 90,5 & 93,2 & 90,9 & 60,1 & 53,5 & 41,8 \\
\hline Latvija & 87,3 & 89,4 & 82,6 & 80,3 & 77,2 & 65,1 \\
\hline Litva & 85,7 & 90,3 & 88,0 & 81,5 & 81,6 & 72,0 \\
\hline Mađarska & 85,7 & 88,9 & 75,9 & 66,5 & 66,4 & 39,1 \\
\hline Nizozemska & 93,7 & 95,5 & 92,1 & 75,3 & 76,5 & 65,1 \\
\hline Austrija & 93,4 & 94,0 & 89,3 & 80,1 & 72,3 & 57,9 \\
\hline Poljska & 83,3 & 86,6 & 83,3 & 69,6 & 66,9 & 57,0 \\
\hline Portugal & 91,5 & 93,6 & 86,8 & 78,0 & 77,5 & 65,8 \\
\hline Rumunjska & 84,4 & 84,9 & 75,3 & 73,9 & 69,1 & 53,4 \\
\hline Slovenija & 91,2 & 94,9 & 94,1 & 84,3 & 87,2 & 84,7 \\
\hline Slovačka & 89,6 & 91,7 & 79,0 & 70,1 & 69,6 & 52,2 \\
\hline Finska & 92,0 & 93,1 & 92,2 & 78,7 & 80,9 & 66,5 \\
\hline UK & 91,5 & 92,7 & 85,4 & 75,5 & 71,0 & 47,9 \\
\hline
\end{tabular}

Izvor: Eurostat (2010.)

Društvena i ekonomska transformacija bivših socijalističkih zemalja u 1990-ima donijela je i usporedno smanjivanje prijašnjih, u socijalističkom razdoblju relativno visokih, stopa zaposlenosti žena. U zemljama s vrlo niskim fertilitetom različit je smjer kretanja participacije žena u radnoj snazi u 1990-ima. Suprotno ranijim desetljećima, u nekima se povećala, a u drugima smanjila. Italija i Španjolska su primjer zemalja s niskom stopom participacije i niskim fertilitetom, ali s trendom povećanja. S druge strane, postsocijalističke zemlje primjer su suprotnoga. Visoka participacija žena na tržištu rada iz socijalističkoga se razdoblja u 1990-ima smanjila. U većini zemalja vrlo niskoga fertiliteta vrijedi pravilo: što žena ima više djece, manji su izgledi da će biti zaposlena (vidjeti Tablicu 4). Isto 
DRUŠ. ISTRAŽ. ZAGREB GOD. 20 (2011), BR. 1 ( 1111$)$

STR. $47-68$

AKRAP, A., ČIPIN, I. USKLAEIVANJE.. vrijedi i za dob djece. Što su djeca mlađa, manja je šansa da će žena biti zaposlena. Mnoga istraživanja pokazala su da što je veći broj djece u kućanstvu i što su djeca mlađa, osjetno se povećavaju negativni učinci usklađivanja poslovnoga i obiteljskoga života (vidjeti npr. Long Dilworth, 2004.). Iz Tablice 4 vidi se da stopa zaposlenosti žena opada s brojem djece koje žena ima. Stope zaposlenosti žena od 25 do 49 godina osobito padnu kada je u obitelji troje ili više djece. Opet, najveći se pad događa u zemljama s vrlo niskim stopama fertiliteta - Bugarskoj Češkoj, Mađarskoj, Njemačkoj, Austriji, Slovačkoj itd. Jedina zemlja gdje stopa zaposlenosti žena s većim brojem djece ne pada jest Slovenija. Istodobno, stopa zaposlenosti muškaraca ne razlikuje se značajno ovisno o broju djece koje muškarac uzdržava.

\section{METODOLOŠKE NAPOMENE}

Empirijski demografski podaci - bilo da je riječ o onima na makrorazini, koje nalazimo u statističkim publikacijama nacionalnih (npr. Državnog zavoda za statistiku u Hrvatskoj) i nadnacionalnih (primjerice Eurostat za Europsku uniju) statističkih agencija ili o onima na individualnoj, mikrorazini (anketna i slična istraživanja na određenom uzorku od interesa) omogućuju nam izvođenje raznih hipoteza i pretpostavki o razlozima nepovoljnih demografskih kretanja unutar jedne zemlje ili više njih ako ih uspoređujemo i na temelju toga donosimo određene zaključke. Tradicionalna demografska analiza, gotovo univerzalno, oslanjala se na podatke na makrorazini, tj. na razini cjelokupne populacije od interesa, bilo da je riječ o jednoj manjoj teritorijalnoj jedinici, poput općine ili grada, ili pak o većoj, poput županije, regije ili države u cjelini, pa čak i grupe država. S druge strane, u novije vrijeme, zahvaljujući sve većem broju anketnih istraživanja na određenom uzorku ispitanika (npr. ankete o fertilitetu), kao i razvoju sofisticiranih statističkih tehnika i softvera koji omogućuju kvalitetnu obradbu prikupljenih podataka, istraživački interes demografa sve se više pomaknuo prema analizi individualnih podataka na mikrorazini.

Empirijska demografska istraživanja fertiliteta na makrorazini u Hrvatskoj imaju dugu tradiciju (vidjeti npr. Wertheimer-Baletić, 1971.; Gelo, 1987.). Nasuprot tomu, demografska istraživanja fertiliteta u Hrvatskoj na mikrorazini tek su se odnedavno počela provoditi (Akrap i sur., 2003.; Akrap i Čipin, 2006.). Premda su ona podignula demografsku analizu fertilitetnih kretanja u Hrvatskoj na višu razinu i, štoviše, empirijska anketna istraživanja danas u suvremenim demografskim radovima europskih i svjetskih demografa dominiraju, ipak nam ona ne mogu potpuno objasniti razloge fertilitetnih 
DRUŠ. ISTRAŽ. ZAGREB GOD. 20 (2011), BR. 1 (111)

STR. $47-68$

AKRAP, A., ČIPIN, I. USKLA'ĐIVANJE... trendova, pa bez analize na makrorazini ne bismo imali spoznaju u kakvu se društvenom kontekstu (npr. kakva je situacija na tržištu rada, kakva je institucionalna potpora ženi i parovima u imanju i podizanju djece, koje su kulturne vrijednosti i norme dominantne $\mathrm{i}$ sl.) događaju promjene $\mathrm{u}$ fertilitetu. Zbog toga smo dosadašnju analizu temeljili na tim agregatnim, makrodemografskim statističkim podacima. No u nastavku ćemo prikazati rezultate na mikrorazini, iz anketnog istraživanja na uzorku od 1309 zaposlenih žena od 20 do 39 godina, koje se provodilo u Hrvatskoj od veljače do travnja 2007. godine. Istraživanje je provedeno opsežnim terenskim anketiranjem na reprezentativnom proporcionalnom kvotnom uzorku na svim područjima (županijama) Hrvatske. Istraživanjem je ispitana populacija zaposlenih žena u Hrvatskoj od 20 do 39 godina, neovisno o bračnom statusu i fertilitetu. Kao istraživački instrument sastavljena je "Anketa o zaposlenosti žena i fertilitetu", koja je imala je 52 pitanja, a koja su obuhvatila široku problematiku kojom se zaposlene žene suočavaju ako / kada žele imati djecu.

U tom anketnom istraživanju jedno od pitanja bilo je i preferirani oblik obitelji. U skladu s teorijskim pretpostavkama o modelima obitelji, ispitanice su mogle zaokružiti odgovore da preferiraju:

a) obitelj gdje oba partnera imaju jednako zahtijevan posao i gdje se kućanski poslovi i briga o djeci jednako dijele među njima

b) obitelj gdje žena ima manje zahtjevan posao nego njezin suprug / partner i gdje ona obavlja većinu kućanskih poslova i vodi brigu o djeci

c) obitelj gdje je samo muž zaposlen, a žena vodi brigu o kućanstvu.

U analizi rezultata upotrijebljena je multinomna logistička regresija te jednosmjerna analiza varijance (ANOVA) uz pripadajuće post hoc testove. Kod modela logističke regresije navedeno pitanje uzeto je kao zavisna varijabla opisujući model dvaju hranitelja, model moderniziranoga muškog hranitelja te tradicionalni model muškoga hranitelja. Izradbom serija modela logističke regresije uzeti su određeni prediktori koji daju najbolje rezultate. Kod jednosmjerne ANOVE, zavisnu varijablu upotrijebljenu $u$ analizi čine izjave žena na tržištu rada, a nezavisnu varijablu broj djece koje su ispitanice dosad rodile. Zavisna varijabla mjerena je na Likertovoj skali od pet stupnjeva (odgovori: slažem se potpuno $=5$, slažem se $=4$, niti se slažem niti ne slažem $=3$, ne slažem se $=2$ i uopće se ne slažem $=1$ ). Nezavisna varijabla kategorijalna je s kategorijama 0, 1, 2 i 3 i više djece. 


\section{REZULTATI I RASPRAVA}

\section{Deskriptivna analiza}

Prvi dio analize deskriptivne je prirode. Teorijske pretpostavke iz uvodnih dijelova rada ispitat ćemo deskriptivnim statističkim pokazateljima iz ankete. Ispitanice su grupirane prema modelima obitelji (model dvaju hranitelja, modernizirani muški hranitelj i model muškoga hranitelja) te su iskazane njihove trenutačne preferencije. Dva su glavna prediktora preferiranog oblika obitelji. Prvi je obrazovni status, gdje smo ispitanice podijelili u tri široke obrazovne grupe (osnovno obrazovanje i niže, srednje te tercijarno obrazovanje). Drugi je prediktor fertilitetni status (bez djece ili s jednim, dvoje te troje $\mathrm{i}$ više). Konačno, dob (dvije kategorije: mlađe: od 20 do 29 i starije: od 30 do 39) uzeli smo kao kontrolnu varijablu.

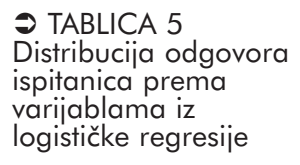

\begin{tabular}{llrr}
\hline & & $\mathrm{N}$ & $\begin{array}{r}\text { Udio } \\
(\mathrm{u} \%)\end{array}$ \\
\hline Modeli obitelji & Dva hranitelja & 1050 & 83,7 \\
& Modernizirani muški hranitelj & 180 & 14,3 \\
& Muški hranitelj & 25 & 2,0 \\
Dob & $20-29$ & 608 & 48,4 \\
Obrazovanje & Osnovno i niže & 647 & 51,6 \\
& Srednje & 34 & 2,7 \\
Broj djece & Tercijarno & 760 & 60,6 \\
& 0 & 461 & 36,7 \\
& 1 & 599 & 47,7 \\
& 2 & 265 & 21,1 \\
& $3+$ & 298 & 23,8 \\
& Ukupno & 93 & 7,4 \\
& & 1255 & 100,0
\end{tabular}

Glavni analitički i statistički alat upotrijebljen u radu jest logistička regresija. Preferirani model obitelji ispitanica uzet je kao zavisna varijabla. Serijom modela logističke regresije ispitali smo značaj mnogih prediktorskih i kontrolnih varijabli, da bismo vidjeli da li i u kojoj mjeri poboljšavaju model. Konačni model uključuje paritete rađanja ispitanica, odnosno broj djece koje su rodile, obrazovni status ispitanica, pa smo kontrolirali i dob ispitanica. Očekujemo da će žene s većim brojem djece preferirati tradicionalni oblik obitelji, model muškoga hranitelja. Isto tako očekujemo da taj model preferiraju žene koje nemaju veći stupanj obrazovanja i one starije.

\section{Preferirani modeli zaposlenosti - nalasci iz analize}

U Tablici 6 nalaze se rezultati iz multinomne logističke regresije, gdje je zavisna varijabla, kao što smo već napomenuli, preferirani model usklađivanja posla i obitelji, a prediktori su 
DRUŠ. ISTRAŽ. ZAGREB GOD. 20 (2011), BR. $1(111)$

STR. $47-68$

AKRAP, A., ČIPIN, I. USKLA'ĐIVANJE...

(1) TABLICA 6

Omjeri šansi preferiranih modela obitelii (dva hranitelia - referentna kategorija) obrazovanje i fertilitetni paritet te dob ispitanica. Podaci $\mathrm{u}$ tablici jesu omjeri šansi uz logističke koeficijente. Referentnu kategoriju čine ispitanice koje preferiraju model dvaju hranitelja. Rezultati iz multinomne logističke regresije pokazuju sljedeće. Naime, žene sa sekundarnim obrazovanjem dvaput su sklonije modelu moderniziranoga muškog hranitelja naspram modela dvaju hranitelja od žena s tercijarnim obrazovanjem. Isto tako, žene sa sekundarnim obrazovanjem znatno su sklonije modelu muškoga hranitelja naspram modela dvaju hranitelja od žena s tercijarnim obrazovanjem. S druge strane, preferencija prema modelu muškoga hranitelja u odnosu na model dvaju hranitelja opada s brojem djece, pa su žene bez djece ili samo s jednim djetetom znatno manje sklone navedenom modelu nego žene koje imaju troje ili više djece. Dob kao kontrolna varijabla nije se pokazala statistički značajnom varijablom, pa možemo ustvrditi da kod preferiranih modela zaposlenosti ne postoje razlike između starijih i mlađih ispitanica.

\begin{tabular}{|c|c|c|c|}
\hline & & $\begin{array}{r}\text { Modernizirani muški hranitelj } \\
\text { vs. dva hranitelja }\end{array}$ & $\begin{array}{r}\text { Muški hranitelj } \\
\text { vs. dva hranitelja }\end{array}$ \\
\hline Dob & $\begin{array}{l}20-29 \\
30-39\end{array}$ & $\begin{array}{l}1,31 \\
1,00\end{array}$ & $\begin{array}{l}0,58 \\
1,00\end{array}$ \\
\hline Obrazovanje & $\begin{array}{l}\text { Osnovno i niže } \\
\text { Srednje } \\
\text { Tercijarno }\end{array}$ & $\begin{array}{l}2,15 \\
2,00^{* * *} \\
1,00\end{array}$ & $\begin{array}{c}7,90 \\
13,92^{* *} \\
1,00\end{array}$ \\
\hline Broj djece & $\begin{array}{l}0 \\
1 \\
2 \\
3+\end{array}$ & $\begin{array}{l}0,47^{*} \\
0,64 \\
0,75 \\
1,00\end{array}$ & $\begin{array}{l}0,29 * \\
0,06^{* *} \\
0,43 \\
1,00\end{array}$ \\
\hline
\end{tabular}

${ }^{*} \mathrm{p}<0,05,{ }^{* *} \mathrm{p}<0,01,{ }^{* * *} \mathrm{p}<0,001$

Ovi rezultati pokazuju da među zaposlenim ženama velika većina preferira model dvaju hranitelja, gdje oba roditelja rade plaćeni posao izvan kućanstva. Model muškoga hranitelja jest preferirani model obitelji kod žena koje imaju tradicionalna shvaćanja o podjeli rada u obitelji i koje imaju troje ili više djece. Model moderniziranoga muškog hranitelja, koji pretpostavlja rad sa skraćenim radnim vremenom, uglavnom preferiraju ispitanice sa srednjom razinom naobrazbe, $\mathrm{u}$ odnosu na one s tercijarnim obrazovanjem. Dodatnom analizom utvrdili smo da je najčešće riječ o ispitanicama iz sektora trgovine i prerađivačke industrije, gdje su uvjeti rada ženama s djecom, ali i financijske okolnosti, relativno nepovoljni.

\section{Stavovi o položaju žena na tržištu rada}

Dodatnu smo statističku analizu napravili koristeći se stavovima ispitanica o položaju žene na tržištu rada s obzirom na paritet. Post-hoc analiza pokazala je da se ispitanice bez djece 
DRUŠ. ISTRAŽ. ZAGREB GOD. 20 (2011) BR. 1 (111)

STR. $47-68$

AKRAP, A., ČIPIN, I. USKLAEIVANJE.. tržištu rada i njezinim obiteljskim obvezama. Manje su sklone (nasuprot ženama s dvoje, a posebice onima s troje ili više djece) tvrdnjama koje sugeriraju da je ženi s djecom mjesto $u$ kući, a ne na tržištu rada. U nekim slučajevima i žene s jednim djetetom imaju slične stavove kao one bez djece. Riječ je o mlađim generacijama, koje, kako pokazuje ovo istraživanje, imaju sve liberalnije stavove o položaju žene na tržištu rada i usklađivanju obiteljskoga i profesionalnoga života. I o tome, prilikom koncipiranja mjera obiteljske i populacijske politike, svakako treba voditi računa.

Produljeno razdoblje ostanka izvan radne snage nakon rođenja djeteta može ženama stvoriti zapreke u ponovnom povratku na tržište rada. Prema podacima Hrvatskoga zavoda za zapošljavanje i Ankete o radnoj snazi, stopa nezaposlenosti žena bila je od 1990-ih uvijek viša od stope nezaposlenosti muškaraca. Rezultati su pokazali da rad sa skraćenim radnim vremenom preferiraju žene s većim brojem djece i one srednje razine obrazovanja. No poslovi sa skraćenim radnim vremenom u Hrvatskoj su relativno rijetki, dijelom i zbog manjka poticaja poslodavcima da osiguraju dovoljan broj takvih radnih mjesta. Štoviše, poslovi sa skraćenim radnim vremenom često su potplaćeni. Kao rezultat toga, kao što smo vidjeli, jako nizak udio svih zaposlenih žena u Hrvatskoj radi sa skraćenim radnim vremenom. Zbog toga nije ni čudno što velika većina ispitanica preferira posao s punim radnim vremenom. Prema istraživanju činitelja fertiliteta u Hrvatskoj (Akrap, 2003.), udane žene s barem jednim djetetom u Hrvatskoj od 20 do 39 godina najviše preferiraju posao s punim radnim vremenom. Na tragu tih i naših rezultata potrebno je da se u okviru širokoga spektra poticajnih pronatalitetnih mjera posebna pozornost posveti izgradnji šroke društvene infrastrukture koja će omogućiti ženi obavljanje dvostruke uloge: zaposlene žene i majke. U svakom slučaju, većom intervencijom države i društva u cjelini pri pomoći zaposlenoj ženi i majci pomoglo bi se i oporavku sadašnje vrlo niske stope fertiliteta u Hrvatskoj. U svakom slučaju, zaposlenost žena i podizanje djece nisu inkompatibilne aktivnosti ako postoji dobro razvijena institucionalna podrška zaposlenoj ženi majci. Ako nije dovoljno razvijena, tada će zaposlene žene reagirati strategijom imanja manjega broja djece od željenoga. Pogotovo u onim zemljama poput Hrvatske, gdje su ekonomsko-egzistencijalni problemi natprosječno naglašeni.

Povećati zaposlenost žena, a istodobno povećati fertilitet, zacijelo nije i neće biti nimalo lak zadatak, no razina fertiliteta u pojedinim zemljama gdje je stopa zaposlenosti žena vrlo visoka pokazuje kako to nije nemoguće. Povećanje stope zaposlenosti žena i stope fertiliteta, kao što pokazuje primjer nordijskih zemalja, nisu dva međusobno isključiva cilja. 


\begin{tabular}{|c|c|c|c|c|c|}
\hline Izjava & Paritet & $\mathrm{N}$ & M & SD & Post-hoc test \\
\hline $\begin{array}{l}\text { Majka koja radi može uspostaviti } \\
\text { topao i prisan odnos sa svojom } \\
\text { djecom kao i majka koja je kod } \\
\text { kuće (ne radi) }\end{array}$ & $\begin{array}{l}0 \\
1 \\
2 \\
3+ \\
\text { Svi }\end{array}$ & $\begin{array}{r}631 \\
273 \\
310 \\
94 \\
1308\end{array}$ & $\begin{array}{l}3,99 \\
4,03 \\
3,95 \\
3,97 \\
3,99\end{array}$ & $\begin{array}{l}1,041 \\
1,062 \\
1,157 \\
1,195 \\
1,084\end{array}$ & Scheffe, nije sig. \\
\hline $\begin{array}{l}\text { Zaposlenje je najbolji način } \\
\text { da žena postane samostalna }\end{array}$ & $\begin{array}{l}0 \\
1 \\
2 \\
3+ \\
\text { Svi }\end{array}$ & $\begin{array}{r}631 \\
273 \\
310 \\
93 \\
1307\end{array}$ & $\begin{array}{l}3,95 \\
3,96 \\
3,95 \\
3,65 \\
3,93\end{array}$ & $\begin{array}{l}0,890 \\
0,939 \\
0,992 \\
1,060 \\
0,940\end{array}$ & Tamhane, nije sig. \\
\hline $\begin{array}{l}\text { Posao kućanice ispunjava } \\
\text { kao i bilo koji drugi posao }\end{array}$ & $\begin{array}{l}0 \\
1 \\
2 \\
3+ \\
\text { Svi }\end{array}$ & $\begin{array}{r}631 \\
272 \\
310 \\
93 \\
1306\end{array}$ & $\begin{array}{l}2,87 \\
2,77 \\
2,80 \\
2,82 \\
2,83\end{array}$ & $\begin{array}{l}1,024 \\
1,069 \\
1,100 \\
1,073 \\
1,055\end{array}$ & Scheffe, nije sig. \\
\hline $\begin{array}{l}\text { I muškarac i žena trebali bi } \\
\text { financijski pridonositi kućanstvu }\end{array}$ & $\begin{array}{l}0 \\
1 \\
2 \\
3+ \\
\text { Svi }\end{array}$ & $\begin{array}{r}631 \\
273 \\
309 \\
93 \\
1306\end{array}$ & $\begin{array}{l}4,40 \\
4,40 \\
4,39 \\
4,33 \\
4,39\end{array}$ & $\begin{array}{l}0,700 \\
0,695 \\
0,711 \\
0,681 \\
0,700\end{array}$ & Scheffe, nije sig. \\
\hline $\begin{array}{l}\text { Predškolsko će dijete vjerojatno } \\
\text { patiti ako mu majka radi }\end{array}$ & $\begin{array}{l}0 \\
1 \\
2 \\
3+ \\
\text { Svi }\end{array}$ & $\begin{array}{r}629 \\
272 \\
310 \\
92 \\
1303\end{array}$ & $\begin{array}{l}2,62 \\
2,72 \\
2,87 \\
3,03 \\
2,73\end{array}$ & $\begin{array}{l}0,964 \\
1,080 \\
1,075 \\
1,172 \\
1,039\end{array}$ & $\begin{array}{l}\text { Tamhane, } 0 \text { vs. } 2 \text { i } 0 \text { vs. } 3 \text {; } \\
\text { sig. } p<0,05\end{array}$ \\
\hline $\begin{array}{l}\text { Imati zaposlenje je dobro, ali ono } \\
\text { što većina žena zapravo želi jesu } \\
\text { kuća i djeca }\end{array}$ & $\begin{array}{l}0 \\
1 \\
2 \\
3+ \\
\text { Svi }\end{array}$ & $\begin{array}{r}624 \\
271 \\
310 \\
93 \\
1298\end{array}$ & $\begin{array}{l}2,46 \\
2,62 \\
2,77 \\
3,14 \\
2,61\end{array}$ & $\begin{array}{l}1,114 \\
1,152 \\
1,134 \\
1,109 \\
1,141\end{array}$ & $\begin{array}{l}\text { Scheffe, } 0 \text { vs. } 2 ; 0 \text { vs. } 3 \text { i } 1 \\
\text { vs. } 3 \text {; sig. } p<0,01\end{array}$ \\
\hline $\begin{array}{l}\text { Iako je zaposlena, glavna bi od- } \\
\text { govornost žene trebala biti briga } \\
\text { o kućanstvu i briga o djeci }\end{array}$ & $\begin{array}{l}0 \\
1 \\
2 \\
3+ \\
\text { Svi }\end{array}$ & $\begin{array}{r}630 \\
273 \\
310 \\
94 \\
1307\end{array}$ & $\begin{array}{l}2,96 \\
3,12 \\
3,16 \\
3,57 \\
3,08\end{array}$ & $\begin{array}{l}1,144 \\
1,139 \\
1,098 \\
1,083 \\
1,138\end{array}$ & $\begin{array}{l}\text { Scheffe, } 0 \text { vs. } 3 \text {; sig. } \\
p<0,001 ; 1 \text { vs. } 3 \\
\text { i } 2 \text { vs. } 3 \text {; sig. } p<0,05\end{array}$ \\
\hline $\begin{array}{l}\text { Žene koje imaju djecu koja još } \\
\text { nisu školske dobi ne bi trebale } \\
\text { raditi, nego bi se trebale brinuti } \\
\text { za djecu }\end{array}$ & $\begin{array}{l}0 \\
1 \\
2 \\
3+ \\
\text { Svi }\end{array}$ & $\begin{array}{r}630 \\
272 \\
310 \\
93 \\
1305\end{array}$ & $\begin{array}{l}2,48 \\
2,53 \\
2,76 \\
3,06 \\
2,60\end{array}$ & $\begin{array}{l}0,909 \\
1,020 \\
0,940 \\
1,041 \\
0,964\end{array}$ & $\begin{array}{l}\text { Tamhane, } 0 \text { vs. } 2 \text {; } 1 \text { vs. } 3 \text { i } 0 \\
\text { vs. } 3 \text {; sig. } p<0,001 ; 1 \text { vs. } 2 \text {; } \\
\text { sig. } p<0,05\end{array}$ \\
\hline
\end{tabular}

(1) TABLICA 7 Stavovi ispitanica o položaju žena na tržištu rada i paritet, post-hoc analiza
Za ostvarenje obaju ciljeva nužna je potpora države, koja bi mjerama za usklađivanje poslovnoga i obiteljskoga života trebala pomoći ženama da, s jedne strane, budu zaposlene, a, s druge strane, da imaju željeni broj djece. Ekonomski poticaji i stanje na tržištu rada, posebno za mlade, važan su faktor 
DRUŠ. ISTRAŽ. ZAGREB GOD. 20 (2011) BR. 1 (111)

STR. $47-68$

AKRAP, A., ČIPIN, I. USKLADIVANJE...

\section{BILJEŠKE}

\section{LITERATURA}

u demografskim objašnjenjima niskoga fertiliteta (Macunovich, 1996.; Hotz i sur., 1997.; Kohler i sur., 2002.). Trend povećanja zaposlenosti žena, započet potkraj 1960-ih sigurno će se nastaviti. Povećanje stope zaposlenosti žena bez dvojbe je nepovratan proces, kojem se trebaju prilagođavati sve društvene i ekonomske strukture, pa tako i one koje imaju veći utjecaj na fertilitet, usklađivanje posla i obitelji te na jednakost među spolovima.

${ }^{1}$ U skladu s Lisabonskim ciljevima za 2010. da Europska unija postane najkompetentnija i najdinamičnija ekonomija utemeljena na znanju, jedan od načina ostvarenja održivoga ekonomskog razvoja jest i povećana integracija žena na tržištu rada, koja je imala za cilj povećanje stope zaposlenosti žena (15-64) na 60\% ili više do 2010.

${ }^{2}$ Institucionalna ograničenja, nepobitno, utječu na zaposlenost žena, posebno kada su djeca mala. U analizi 14 europskih zemalja Kotowska i Matysiak (2008.) potvrdile su poznatu činjenicu da je režim blagostanja koji najviše podupire zaposlene žene majke onaj koji osigurava javnu potporu za usklađivanje poslovnih i obiteljskih obveza. Zemlje s režimom blagostanja koji utječe na polarizaciju ponašanja na tržištu rada imaju niske stope fertiliteta i zaposlenosti žena. Unatoč tomu što su našle da je institucionalno okruženje od velike važnosti u omogućavanju usklađivanja poslovnoga i obiteljskoga života, nisu potvrdile hipotezu da će fertilitetne intencije biti više u zemljama koje imaju podupiruće režime blagostanja te da su drugi činitelji, osim institucionalnog okruženja, važni u sadašnjim fertilitetnim intencijama. Ovi rezultati, premda zanimljivi, prema našem mišljenju, imaju ograničenja s obzirom na izbor zemalja koje predstavljaju pojedine oblike režima blagostanja te modela koji se tiču obitelji i partnerstva, gdje nedostaju u prvom redu nordijske zemlje i Francuska, a realno je pretpostaviti da bi tada rezultati bili drugačiji. Unatoč svemu, našle su da u zemljama koje imaju najmanju potporu zaposlenim ženama majkama preferencije da imaju samo jedno dijete vidljivo su jače nego u drugim režimima blagostanja.

3 Dodatnim izračunima, kada smo izbacili outliere Sloveniju i Irsku, koeficijent korelacije porastao je na 0,55.

4 Podaci za Hrvatsku nisu nam bili dostupni.

5 Taj se udio penje na više od $80 \%$, kada izuzmemo mlađe od 25 godina, od kojih se osjetan broj neaktivnih nalazi u obrazovnom sustavu.

Ahn, N. i Mira, P. (2002.), A Note on the Changing Relationship between Fertility and Female Employment Rates in Developed Countries. Journal of Population Economics, 15 (4): 667-682.

Akrap, A. (2003.), Istraživanje činitelja fertiliteta u Hrvatskoj. U: A. Akrap, I. Čipin, N. Pokos, T. Ridzak i D. Živić (ur.), Činitelji demografskih kretanja u Republici Hrvatskoj (str. 85-162), Zagreb, Državni zavod za zaštitu obitelji, materinstva i mladeži. 
DRUŠ. ISTRAŽ. ZAGREB GOD. 20 (2011), BR. 1 ( 111 1)

STR. $47-68$

AKRAP, A., ČIPIN, I.: USKLADIVANJE...
Akrap, A. i Čipin, I. (2006.), Socijalitetni sterilitet u Hrvatskoj - Zašto smo neoženjeni $i$ neudane, Zagreb: Ministarstvo obitelji, branitelja i međugeneracijske solidarnosti.

Akrap, A., Čipin, I., Pokos, N., Ridzak, T. i Živić, D. (2003.), Činitelji demografskih kretanja u Republici Hrvatskoj, Zagreb: Državni zavod za zaštitu obitelji, materinstva i mladeži.

Baloban, J. (ur.) (2005.), U potrazi za identitetom - komparationa studija vrednota: Hrvatska i Europa, Zagreb: Golden marketing - Tehnička knjiga.

Becker, G. (1991.), A Treatise on the Family, Cambridge, Mass.: Harvard University Press.

Bernhardt, E. (1993.), Fertility and Employment. European Sociological Review, 9 (1): 25-42.

Billari, F. C. i Kohler, H.-P. (2004.), Patterns of Low and Very Low Fertility in Europe. Population Studies, 58 (2): 161-176.

Brewster, K. i Rindfuss, R. (2000.), Fertility and Women's Employment in Industrialized Countries. Annual Review of Sociology, 26 (1): 271-296.

Clarkberg, M. i Moen, P. (2001.), Understanding the Time-Squeeze Married Couples' Preferred and Actual Work-Hours Strategies. American Behavioural Scientist, 44 (7): 1115-1135.

Del Boca, D. (2002.), The Effect of Child Care and Part Time Opportunities on Participation and Fertility Decisions in Italy. Population Economics, 15 (3): 549-573.

Delgado, M., Meil, G. i Zamora López, F. (2008.), Spain: Short on Children and Short on Family Policies. Demographic Research, 19 (27): 1059-1104

DiPrete, T. A., Mogran, S. P., Engelhardt, H. i Pacalova, H. (2003.), Do Cross-National Differences in the Cost of Children Generate Cross-National Differences in Fertility Rates? Population Research and Policy Review, 22 (5-6): 439-477.

DZS (2001.), Popis stanovništva, kućanstava i stanova 31. ožujka 2001., Zagreb: Državni zavod za statistiku.

Engelhardt, H. i Prskawetz, A. (2004.), On the Changing Correlation between Fertility and Female Employment Over Space and Time. European Journal of Population, 20 (1): 35-62.

Esping-Andersen, G. (1999.), Social Foundations of Postindustrial Economies, Oxford: Oxford University Press.

European Commission (2005.), Confronting Demographic Change: A New Solidarity between the Generations. Green Paper, Brussels: Commission of the European Communities.

Eurostat (2010.), Population and Social Conditions. Dostupno online na: http://epp.eurostat.ec.europa.eu (15. 2. 2010.).

Gauthier, A. H. (1996.), The State and the Family: A Comparative Analysis of Family Policies in Industrialized Countries, New York: Oxford University Press.

Gelo, J. (1987.), Demografske promjene u Hrvatskoj od 1780. do 1981. godine, Zagreb: Globus. 
DRUŠ. ISTRAŽ. ZAGREB GOD. 20 (2011), BR. 1 (111)

STR. $47-68$

AKRAP, A., ČIPIN, I.: USKLAEIVANJE..
Hotz, J., Klerman, J. i Willis, R. (1997.), The Economics of Fertility in Developed Countries. U: M. Rosenzweig i O. Stark (ur.), The Handbook of Population and Family Economics (str. 276-347), Amsterdam, Elsevier Science, North Holland.

Ilišin, V. (2007.), Društveni status, problemi i budućnost mladih. U: V. Ilišin i F. Radin (ur.), Mladi: problem ili resurs (str. 39-84), Zagreb, Institut za društvena istraživanja u Zagrebu.

Kohler, H.-P., Billari, F. C. i Ortega, J. A. (2002.), Towards a Theory of Lowest-Low Fertility. Population and Development Review, 28 (4): 641-680.

Kotowska, I. E. i Matysiak, A. (2008.), Reconciliation of Work and Family under Different Institutional Settings. U: C. Höhn, D. Avramov i I. E. Kotowska (ur.), People, Population Change and Policies: Lessons from the Population Policy Acceptance Study, vol. 1 (str. 299-318), European Studies of Population, Springer.

Liefbroer, A. C. (1999.), From Youth to Adulthood: Understanding Changing Patterns of Family Formation from a Life Course Perspective. U: L. J. G. van Wissen i P. A. Dykstra (ur.), Population Issues. An Interdisciplinary Focus (str. 53-86), New York/London, Kluwer Academic/Plenum Publishers.

Long Dilworth, J. E. (2004.), Predictors of Negative Spillover from Family to Work. Journal of Family Issues, 25 (2): 241-261.

Macunovich, D. J. (1996.), Relative Income and Price of Time: Exploring their Effects on US Fertility and Female Labor Force Participation. Population and Development Review, 22 (supplement): 223-257.

McDonald, P. (2000.), Gender Equity in Theories of Fertility Transition. Population and Development Review, 26 (3): 427-439.

Neyer, G. R. i Andersson, G. (2008.), Consequences of Family Policies on Childbearing Behaviour: Effects or Artifacts? Population and Development Review, 34 (4): 699-724.

Neyer, G. R. (2003.), Family Policies and Low Fertility in Western Europe. Journal of Population and Social Security 1 (supplement), 46-93.

Palomba, R. (2003.), Reconciliation of Work and Family. U: R. Palomba i I. E. Kotowska (ur.), The Economically Active Population in Europe (str. 11-53), Population Studies 40, Council of Europe: Strasbourg.

Pokos, N. (1999.), Procjena broja iseljenih stanovnika Republike Hrvatske od popisa stanovništva 1991. do 30. lipnja 1998. godine. Društvena istraživanja, 8 (5-6): 725-734.

Roxburgh, S. (1999.), Exploring Work and Family Relationship. Journal of Family Issues, 20 (6): 771-788.

Vignon, J. (2005.), Responses to the New Demographics in Europe Present and Future Strategies for the European Union. U: M. Macura, A. MacDonald i W. Haug (ur.), The New Demographic Regime, Population Challenges and Policy Responses (str. 45-56), United Nations, New York i Geneva.

Wertheimer-Baletić, A. (1971.), Stanovništvo SR Hrvatske - Studije, Zagreb: Školska knjiga. 
DRUŠ. ISTRAŽ. ZAGREB GOD. 20 (2011), BR. 1 (111)

STR. $47-68$

AKRAP, A., ČIPIN, I.: USKLA'ĐIVANJE...

\section{Combining Work and Family Life in Croatia and Their Influence on Fertility}

Anđelko AKRAP, Ivan ČIPIN

Faculty of Economics and Business, Zagreb

The dual-earner family is increasingly becoming a norm in the majority of developed countries. The aim of this paper is to investigate how developed is the infrastructure for combining family and work and what type of family models are preferred by employed women in Croatia. In the survey, based on a sample of 1309 employed women aged 20-39, different statistical techniques were applied to find their preferred family model and attitudes on women's labor market position. The results show that a large majority of employed women prefer the dual-earner model, where both parents have paid work outside of the household. Moreover, younger generations of women have more liberal views on women's position in the labor market. To increase women's employment and fertility in the same time is no easy task, but experience from countries where high women's employment rate coexists with higher fertility rate show it is not impossible. We conclude that the lack of possibility for part-time work in Croatia imposes a barrier for women who want to combine professional and family responsibilities.

Keywords: fertility, combining professional and family responsibilities, employed women

\section{Vereinbarung von Beruf und Familie: Auswirkungen auf die Geburtenrate in Kroatien}

Anđelko AKRAP, Ivan ČIPIN

Wirtschaftswissenschaftliche Fakultät, Zagreb

In den meisten Industriestaaten ist es mittlerweile normal, dass beide Elternteile berufstätig sind. In dieser Arbeit soll untersucht werden, inwiefern eine Infrastruktur vorliegt, die die Vereinbarung von Beruf und Familie möglich macht, und welches Familienmodell die berufstätigen Fraven in Kroatien bevorzugen. Grundlage dieser Untersuchung ist eine Umfrage, an der 1309 berufstätige Fraven zwischen 20 und 39 Jahren teilnahmen und bei der, anhand verschiedener statistischer Techniken, die bevorzugten Familienmodelle ermittelt wurden sowie die Einschätzungen der Umfrageteilnehmerinnen zur Stellung der Frau auf dem Arbeitsmarkt. Die vorliegende Untersuchung ergab, dass die große Mehrheit der Fraven die Berufstätitgkeit beider 
DRUŠ. ISTRAŽ. ZAGREB GOD. 20 (2011) BR. $1(111)$

STR. $47-68$

AKRAP, A., ČIPIN, I.: USKLA'EIVANJE...
Elternteile bevorzugt, d.h. das Einfließen zweier Gehälter in die gemeinschaftliche Haushaltskasse aufgrund von beruflicher Tätigkeit außerhalb des Hauses. Ferner haben junge Frauen liberalere Einstellungen zur Stellung der Frau auf dem Arbeitsmarkt. Es ist sicherlich keine leichte Aufgabe, die Beteiligung der Frauen am Arbeitsmarkt und gleichzeitig die Geburtenrate zu steigern, und wird es auch in Zukunft nicht sein. Doch die Geburtenraten in Ländern, in denen die Zahl der berufstätigkeiten Fraven sehr groß ist, zeigen, dass das durchaus möglich ist. Der Verfasser kommt zu dem Schluss, dass es für Frauen in Kroatien, die Beruf und Familie unter einen Hut bringen wollen, ein großes Hindernis darstellt, ihren Beruf nicht bei verkürzten Arbeitszeiten ausüben zu können.

Schlüsselbegriffe: Geburtenrate, Vereinbarung von Beruf und Familie, berufstätige Fraven 